Pp.139 -155

DOI: http://dx.doi.org/10.24093/awejtls/vol5no2.11

\title{
Translation and the Individual Talent: Ambiguity in the Qur' anic Text and the Role of the Translator
}

\author{
Raed A. Qassas \\ Department of Languages and Translation \\ Taibah University, Kingdom of Saudi Arabia \\ Email: rqasass@ taibahu.edu.sa
}

Received: 2/25/2021

Accepted: 5/10/2021

Published: 5/24/2021

\begin{abstract}
This article examines the impact of traditional Tafsìr, the exegesis of the Qur'an, on the translation of the Qur' anic text into English. Caught between the authority of tradition and the sensitivity of translating a sacred text, many translators refrain from practicing interpretation as an integral part of the translation process, whereas others defiantly dismiss the authority of tradition en masse. The significance of the study lies in undermining over-reliance on explanatory texts yields semantically dogmatic interpretations recurrently manifest in the various English renditions of the Qur'an. The article questions what is called the etic translation that involves translation from the perspective of one who remains an outsider and does not participate in the interpretation. The finding of the study lead to the conclusion that many translations of the Qur'an disregard possible interpretations because of rehashing interpretations handed down from traditional exegeses. The article also argues that translators have an active, interpretative role in the translation of the Qur'an. Compatibility with tradition does not mean being constricted exclusively by Tafsìr. Tradition is a frame of reference, a point of departure for new horizons of interpretation where interpretation is viewed as an augmentation to tradition, not sedition.
\end{abstract}

Keywords: ambiguity, explanation, interpretation, mediation, Qur'an, tradition, translator's role, individual talent

Cite as: Qassas, R. A. (2021). Translation and the Individual Talent: Ambiguity in the Qur'anic Text and the Role of the Translator. Arab World English Journal for Translation \& Literary Studies 5 (2) 139 -155. DOI: http://dx.doi.org/10.24093/awejtls/vol5no2.11 


\section{Introduction}

The translation of any text rests upon the commonplace assumption that a translator must have a thorough knowledge of both the Source Language and the Target Language. However, this assumption does not guarantee all the time the production of a flawless translation. This is especially evident when translating religious texts from Arabic into English, mainly the Qur'anic text. In addition to the thorough knowledge of the SL and the TL, the translator who undertakes the translation of the Qur' an should have interpretative, hermeneutic tools. When such devices are lacking, misinterpretation is likely to occur. The significance of this study is to explore how to avoid misinterpretation and translational complications when dealing with ambiguous verses in the Qur'an. Translators usually resort to Tafāsī ${ }^{1}$ that mediate the interpretation, and rather than translating the Qur'anic text itself, the end product is translating the meanings found in Tafāsīr.

\section{Literature Review}

Translating the Qur'an without reliance on authority is a sensitive issue in the consciousness of Muslims because of the firmly held belief that the Qur'an contains God's words in Arabic, and no other language is appropriate to convey these words except Arabic. The overreliance on Tafāsìr is a part of this sensitivity, and some translators are wary of informing the reader right in the very title that what they have translated is not the Qur'an but its meaning. Ali and Pickthall are two cases in point; their titles respectively are The Holy Qur'an: English Translation of the Meanings and Commentary and The Meaning of the Glorious Qur'an: An Explanatory Translation. In Saheeh International, published anonymously, the translators assert in a footnote that " $[\mathrm{t}] \mathrm{h}$ e words of Allah can never be translated literally. Therefore, it is incorrect to use the term 'translation of the Qur'an.' What is rendered into other languages can be no more than a brief Tafsīr" (Assami, Kennedy \& Bantley, 1997, p. i). Translating the Qur'an without reliance on the authority of tradition is considered precarious, if not seditious, because the general belief is that "tradition-based tafsir is the only tafsir that should be followed because it is the path to true knowledge. It is the safest way of guarding against falling into errors and deviation from the Qur'an" (Qattan, 2009, p. 340). Tafāsìr are considered the legitimate authority of interpretation, and the translator acquires legitimacy for the translation when relying on such Tafāsīr.

In their exegeses, Mufassirs primarily follow a method which states that the Qur'an explains itself, and this implies that ambiguous verses can be understood by referring to other verses that have the same lexical items where the meaning is clear. This method is known as "the interpretation of the Qur' an through the Qur' an itself" (Ibn Kathīr, 2000, p. 6). It is a kind of Arabic sola scriptura, to quote the Reformation's famous slogan, that has become a primary caveat for interpreting the Qur'an. If this method does not work, Mufassirs refer to the sayings of the Prophet, the Sahāba (his Companions), the Tabi'ün (the generation following the Companions), or else, other well-known scholars. Rarely do translators follow the primary method of Ibn Kathīr, i.e., the interpretation of the Qur'an through the Qur'an itself, and more often than not, they resort to Tafāsìr for interpretation, including Ibn Kathīr's Tafsīr al-Qur'ān al- 'Azìm.

Resorting to Tafāsīr, translators find themselves caught in an intertextual, exegetical labyrinth. The interpretative Tafāsīr encroach on the translational rendition of the Qur'anic text 
despite, and maybe because of, the translators' caution to remain faithful to the meaning of the original. Decrying Colin Turner's excessive reliance on Tafāsìr in his translation, Brannon Wheeler (2002) states, "This translation is very readable, but there is no way to distinguish the additional exegetical comments from the text of the Quran" (p. 364). This kind of translation is referred to as an etic rendition of the Qur' an, which involves translating a text from the perspective of one who remains an outsider and does not participate in the direct interpretation of the translated text.

Translation becomes more complicated when the translator favors one interpretation or more, while excluding others, probably due to the translator's mental make-up, preference, sectarian allegiance, or bias. The English rendition of the Qur' anic text has been subject to a kind of eclectic inter-textuality since the appearance of the first translation of the Qur' an by Alexander Ross of the French translation by André du Rye in 1647. Rye acknowledges his heavy reliance on recognized exegeses. In his translation of the Qur' an in 1734, George Sale also acknowledges his indebtedness to explanatory texts such as Al-Baidhāwi, Ibn al-Athīr, al Zamakhshari, and alThalābi, and Al-Tirmidhi, not to mention non-Arabic texts such as Ludovico Marracci's Latin translation of the Qur' an. Sale (2017) states in his introduction:

In the notes, my view has been briefly to explain the text, and especially the difficult and obscure passages, from the most approved commentators, and that generally in their own words ... and the little I have added of my own, or from European writers, being easily discernible. (pp.8-9)

Beneath the various English translations of the Qur' an, therefore, there is an infrastructure of other interwoven texts such as Jämi al-Bayān 'an Ta'wīl Ay al-Qur'an [The Comprehensive Interpretation of the Verses of the Qur'an] by al-Tabarī, Al-Kashf wa al-Bayān [The Revelation and Interpretation] by al-Thalābi, Al-Kashshaaf 'an Haqa'iq at-Tanzil [The Revelation of the Truth of the Qur'an], a seminal Tafsìr by Al-Zamakhshari, and Al-Jami 'li-Ahkäm al-Qur'an [The Comprehensive Interpretation of the Qur'anic Laws] by Al-Qurtubi, just to name a few. Besides, there is a host of other French and Latin texts which interweave with the Arabic sources in some translations. In his preface to The Koran, Rodwell (1994) enumerates the sources he uses in his translation:

The Arabic text from which this translation has been made is that of Fluegel [Leipzig], 1841. The translations of Sale, Ullmann, Wahl, Hammer von Purgstall in the Fundgruben des Orients, and M. Kasimirski, have been collated throughout; and above all, the great work of Father Maracci ... the works of Geiger, Gerock, and Freytag, and to the lives of Muhammad by Dr. Weil, Mr. Muir, and that of Dr. Sprenger now issuing from the press, in German. (pp.16-17)

The meaning the reader finds in the English rendition is the meaning informed by Tafāsis and other texts such as the ones mentioned by Rodwell. It is not the meaning the translator directly grasps from the Qur'anic text. In general, Tafäsìr are considered reliable sources to explain ambiguous verses in the Qur' an. However, when the task is translating the Qur' an, the vast number of Tafāsìr could be a source of perplexity to the translator as to which interpretation to include because 
"[t]raditional commentators have often given multiple conflicting opinions regarding particular verses" (Nasr, Dagli, Dakake, Lumbard, \& Rustom, 2015, p. xliv). Bantley, one of the three translators who produced Saheeh International, admits the difficulty the translator encounters because of the proliferation of meanings and the pressure the translator undergoes in making choices between divergent interpretations. Commenting on her contribution, she states:

It differed from other projects because of the amount of research it took to accurately reflect accepted meanings of the Koran while being limited to the confines of English grammar. Some Koranic passages hold more than one meaning, while in translation, you can usually only reflect one of the intended meanings. (Boyle, 2017, p. 13)

This translation method could be described as translation by proxy where the meanings rendered are the ones concretized by Mufassirs, not the translators. Can translators reflect their understanding of the Qur'anic text in their translation and sidestep Tafāsīr? A genuine hermeneutical reading, according to Hans-Georg Gadamer, does not require exegetes, interpreters, and commentators as mediators. There is a need for "demythologizing" the works of the theologians, states Gadamer (2008), because one can never reach a proper understanding of the sacred text "if it does not seem to speak directly" to the reader (pp.57-58). Nevertheless, there is a widely held notion that the Qur' an should not be interpreted individually based on this Hadith:

Beware of narrating from me except what I taught you, for whoever lies about me on purpose, then let him take his abode in Hell. And whoever says (something) about the Qur' an according to his own opinion, then let him take his abode in Hell. (Al-Tirmidhi, 1996, p. 66)

According to-Doğan (2015), some Sahāaba were extremely careful to produce any Tafsìr, while others produced Tafsir cautiously because "the Prophet (PBUH) had warned his people about making tafsīr of the Qur'ān without relying on evidence. This reluctance and the fear of making a mistake in interpretation passed on to further generations" (2015, p. 1.7). However, this Hadìth contra Tafsìr is graded as $d a a^{\prime} \bar{f}$ or $w_{e a k^{2}}$ by various Hadīth scholars including Muhammad Nāṣir al-Dīn al-Albānī, a contemporary scholar, yet translators seem to adamantly adhere to it and refrain from performing their hermeneutic role. The general tendency is to rely on traditional interpretations that have been already recognized and circulated. The translators of the Qur'an have performed what Friedrich Schleiermacher calls a "grammatical translation," i.e., a mechanical task of transforming a text from one language into another. Translators are still wary in terms of being active in the hermeneutic sphere, and their translation is void of the hermeneutic touch.

The notion that the Qur'an should not be interpreted by the translator impedes the translator's fulfillment of the hermeneutic responsibility, which is not only a professional imperative but an ethical one as well. Over-dependence on traditional exegetical works renders translation a mere copy of the textual glosses or commentaries found in Tafăsìr. Translators must be masters of understanding, says Schleiermacher (2012), and this entitles them to give the readers that self-same understanding:

Arab World English Journal for Translation \& Literary Studies 
To be sure, whoever has mastered this art of understanding by studying the language with diligence, acquiring precise knowledge of the entire historical life of a people and picturing keenly before him the individual works and their authors - he, to be sure, and he alone is justified in desiring to bring to his countrymen and contemporaries just this same understanding of these masterworks of art and science. [Italics mine] (p. 47)

Moreover, a translation in which the translator practices the role of an interpreter is in accord with the injunction of the Qur' an to exercise Taddabur, a term which signifies the individual's mental engagement with the Qur'anic text. In this sense, it is the practice of in-depth reading Qur'anic text that is similar to the concept of close reading advocated by New Criticism.

According to Schleiermacher (2012), translation is a hermeneutic art during which "the translator ascends higher and higher above the interpreter until he reaches the realm most properly his" (2012, p. 45). To examine Schleiermacher's dictum and to check whether the translator can exercise the hermeneutic imperative and interpret the Qur' an without reliance on Tafäsis r the

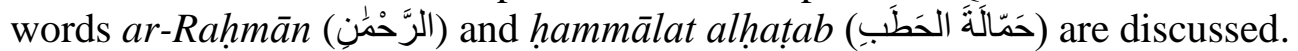

\section{Discussion}

\section{Hammālat al-haṭab: Umm Jamīl vs. Hell}

Hammälat al-hațab (حَمَّالَةَ الحَطَب), i.e., the carrier of firewood, is a problematic noun phrase for translators. Verse 4, chapter 111 (al-Masad), slanders Umm Jamīl, along with her husband Abu Lahab, the uncle of Prophet Muhammed. Part of the difficulty in translating this verse is that Mufassirs have been at a loss to what hammälat al-hațab means and how it is relevant to libeling Umm Jamīl. The result was producing many interpretations exceeding any other verse in the Qur'an. Tafäsīr interpret hammālat al-hațab varyingly as follows:

1. a carrier of firewood, i.e., a load of sins

2. a carrier of evil tales and a slanderer who used to create hatred among people

3. an assistant in the punishment of her husband by throwing firewood on him,

4. an evil woman who used to throw thorns in the way of the Prophet to impede his movement

5. an insult to Umm Jamīl for logging in retort to her belittling of Mohammed for his poverty.

Mufassirs have taken pains to interpret the carrier of firewood to produce these five major interpretations. However, all these meanings cannot be inferred directly from the Qur'anic text, and the various translations of this verse are commonly informed by these Tafäsìr. Here is how Asad (2012) translates the chapter:

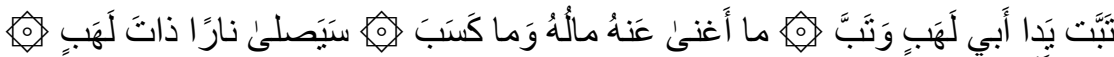

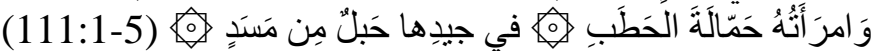

Doomed are the hands of him of the glowing countenance and doomed is he! $\$$ What will his wealth avail him, and all that he has gained? [In the life to come] he shall have to endure a fire fiercely glowing; together with his wife, that 
carrier of evil tales, [who bears] around her neck a rope of twisted strands! (p. 1242)

The first three verses deal with Abu Lahab and his punishment in Hellfire because he did not believe in his nephew's message and aggressively opposed him. His nickname, Abu Lahab ${ }^{3}$, is translated by Asad as one who has a glowing countenance, whereas the literal translation is "the father of flame" (Ali, 1990, p. 2026). No translator, not even an Arabic native translator, can infer that $A b u$ Lahab means a man of glowing countenance because of his ruddy complexion. In a footnote, Asad explains how his translation is influenced by the Tafāsīr of al-Baghawi, alZamakhshari, al-Rāzī, and Al-Bukhāri (p. 1034). Asad's translation of Abu Lahab's name is acceptable since the external exegetical sources have the same meaning. However, in his translation of the carrier of firewood, Asad (2012) translates it as that carrier of evil tales. He supplements his translation of the verse with this footnote:

Her hatred of Muhammad and his followers was so intense that she would often, under the cover of darkness, scatter thorns before the Prophet's house with a view to causing him hurt; and she employed her great eloquence in persistently slandering him and his message. (p. 1243)

Asad opts for only two interpretations out of the five mentioned in Tafāsīr, and his translation yields one metaphorical interpretation in the text supplemented by another literal one in the footnote. Other translators, such as Pickthall and Arberry, render the same verse only literally, whereas Khan and Hilali include both the literal and the metaphorical meanings in the translated text:

Pickthall (2002): And his wife, the wood carrier (p. 690)

Arberry (1996): and his wife, the carrier of the firewood (p. 353)

Khan and Hilalī (1984): And his wife too, who carries wood (thorns of Sadan which she used to put on the way of the Prophet (Peace be upon him), or use to [sic] slander him) (p. 854)

Khan and Hilalī's (1984) choice to have two meanings together makes their translation clogged with surplus interpretations such an extent that might confuse the reader. The last phrase, "or use to slander him," seems out of context since it lacks a sufficient explication about the Arabic idiomatic expression of carrying wood to mean slandering. The translation of Asad (2012) is more acceptable and niftier than Khan and Hilalī's in this regard.

The translator who approaches this verse faces the Gordian knot of translation: The meaning the translator has to choose if there is more than one. This echoes Bantley's statement that "in translation, you can usually only reflect one of the intended meanings" (Boyle, 2017). Asad prefers the carrier of evil tales and the slanderer to any other meaning proposed by Mufassirs. However, there is nothing in the sources that could have given Asad a clue to the more acceptable meaning. Ibn Kathīr (2000) does not favor one interpretation over the other interpretations he includes in his Tafäsìr. He adds a further interpretation according to which the wife of Abu Lahab will have the role of carrying firewood to throw at her husband while tortured in Hell (p. 497). The 
same interpretation is also found in Al-Tafsìr Al-Kabir by Ibn Taymiyyah (2012, p. 110). Another meaning which reads carrying firewood on one's back as carrying a load of sins is found in $\mathrm{Al}$ Jami 'li Ahkam al-Qur'an by al-Qurtubi (2006, p. 240) and Fath al-Qadīr by al-Shawkānī (1994, p. 691). The exclusion of specific interpretations stamps the translation with hermeneutic restrictions on the reader.

Another reading of the chapter, apart from Tafāsìr, reveals another possible meaning relevant to Umm Jamīl's punishment. This meaning, however, is not easily recognized because it is concealed behind a complex form of ellipsis that does not allow direct recovery of the omitted word. According to Levinson (2000), the recovery of the omitted linguistic material is not always straightforward:

In many structural loci, ellipsis is a fundamentally linguistic, rule governed process, so that recovery of omitted material can in fact be thought of as guided by syntactic and semantic principles. But it is clearly not true for examples ... where complex reasoning and not rule application is involved in proposition recovery (pp.183-184).

Chapter 111 has two ellipses: subject ellipsis in verse three and verb ellipsis in verse four. The omitted subject in verse three can be easily recovered, while the verb omitted in verse four cannot. Due to ellipsis in verse three, the subject of the verse $\mathrm{He}$ is omitted:

Shall have to endure a fire fiercely glowing

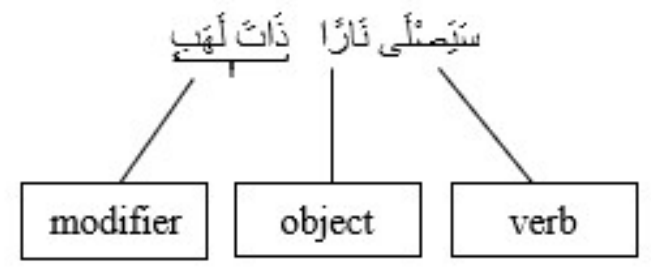

Figure 1. The Arabic omission of subject

The omission of the subject he (ه), which refers to Abu Lahab, serves the avoidance of unnecessary repetition. In Arabic, it is acceptable, in fact typical, to have a statement without a subject that is understood from the context. The recovery of the omitted subject is attainable, and Asad's translation reinstates the omitted subject to render the English translation semantically meaningful and grammatically sound:

(He) shall have to endure a fire fiercely glowing

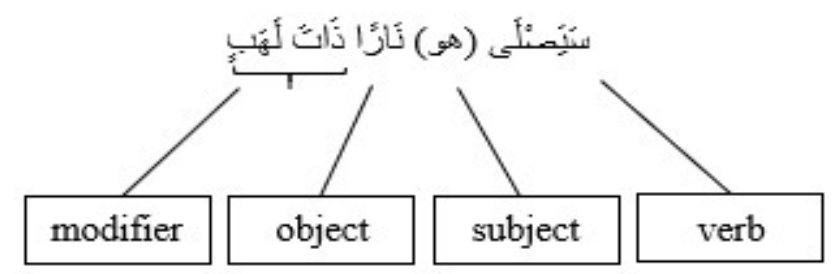

Figure 2.A restoration of the omitted subject

Arab World English Journal for Translation \& Literary Studies

ISSN: 2550-1542 | www.awej-tls.org 
The reinstated subject he allows for coordination between two subjects: He (Abu Lahab) and his wife the carrier of firewood. However, the coordination of the two subjects is very unusual since it sets the two subjects widely apart, with the latter subject deferred as shown in Figure three:

He shall have to endure a fire fiercely glowing and his wife the carrier of firewood.

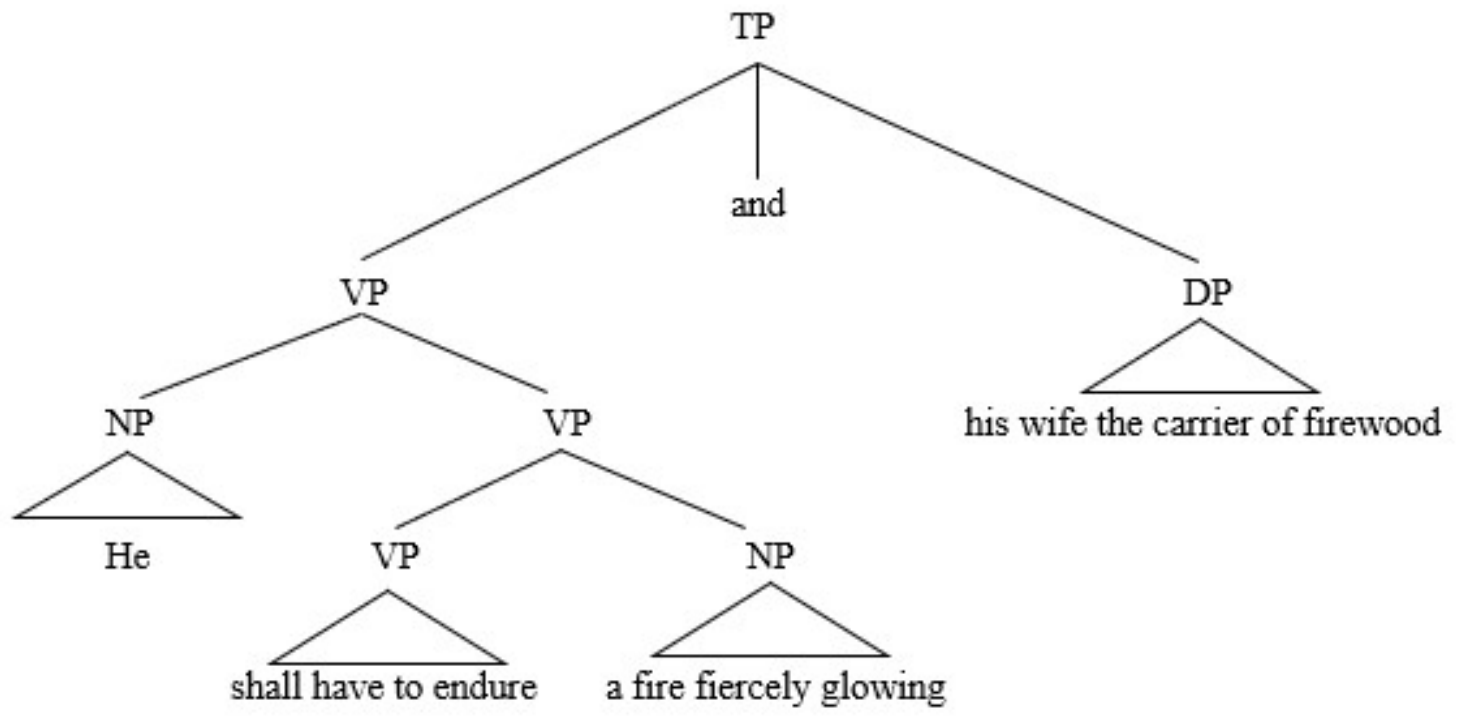

Figure 3.The second subject deferred

Reconstructing the sentence without the deferral of the noun phrase his wife the carrier of firewood, the subject of the sentence becomes a compound subject: He and his wife the carrier of firewood as shown in Figure four:

He and his wife the carrier of firewood shall have to endure a fire fiercely glowing.

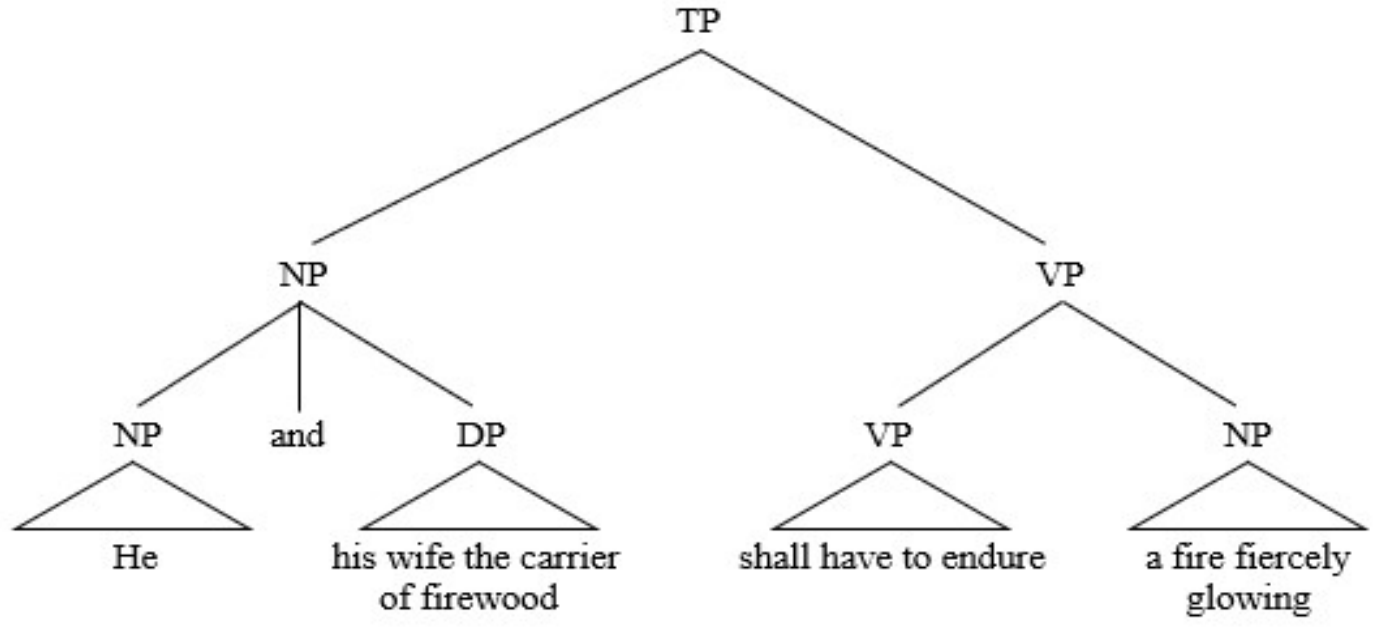

Figure 4.The first and the second subjects re-combined

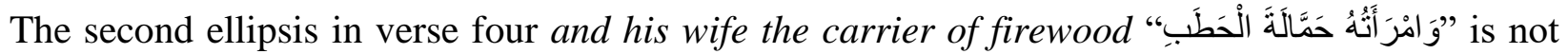
easily recognized because it is elliptical gapping which is "[a] term coined by Ross (1970) to describe a transformation which creates gaps in a sentence after a conjunction by deleting a verb

Arab World English Journal for Translation \& Literary Studies 
which would otherwise reappear, e.g., Caroline plays the flute and Louise (plays) the piano" (Bussmann, 1996, p. 449). Similarly, the verb سَتََّْْْ shall have to endure is omitted because it has already been mentioned in the previous verse about Abu Lahab, but it is still dormant between the subject and the object:

And his wife (shall have to endure) the carrier of firewood

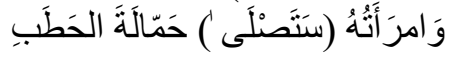

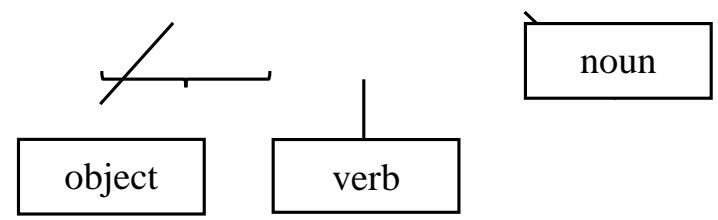

Figure 5.A restoration of the concealed verb

According to Winkler (2005), gapping is characterized by the presence of a second conjunct (clause) that lacks a syntactic constituent but still contains remnant or orphan words. The reader can still understand the meaning out of the remnant words, as in the example provided by Bussmann (1996), "Caroline plays the flute and Louise the piano" (p. 449). The verb plays is omitted because it is repetitious and unnecessary, and the remnants in the second conjunct are Louise and the piano. Similarly, verse four in al-Masad has the remnants his wife and the carrier of firewood after the omitted verb shall have to endure. The omitted verb in the second conjunct is reinstated in Figure six:

He shall have to endure a fire fiercely glowing, and his wife shall have to endure the carrier of firewood.

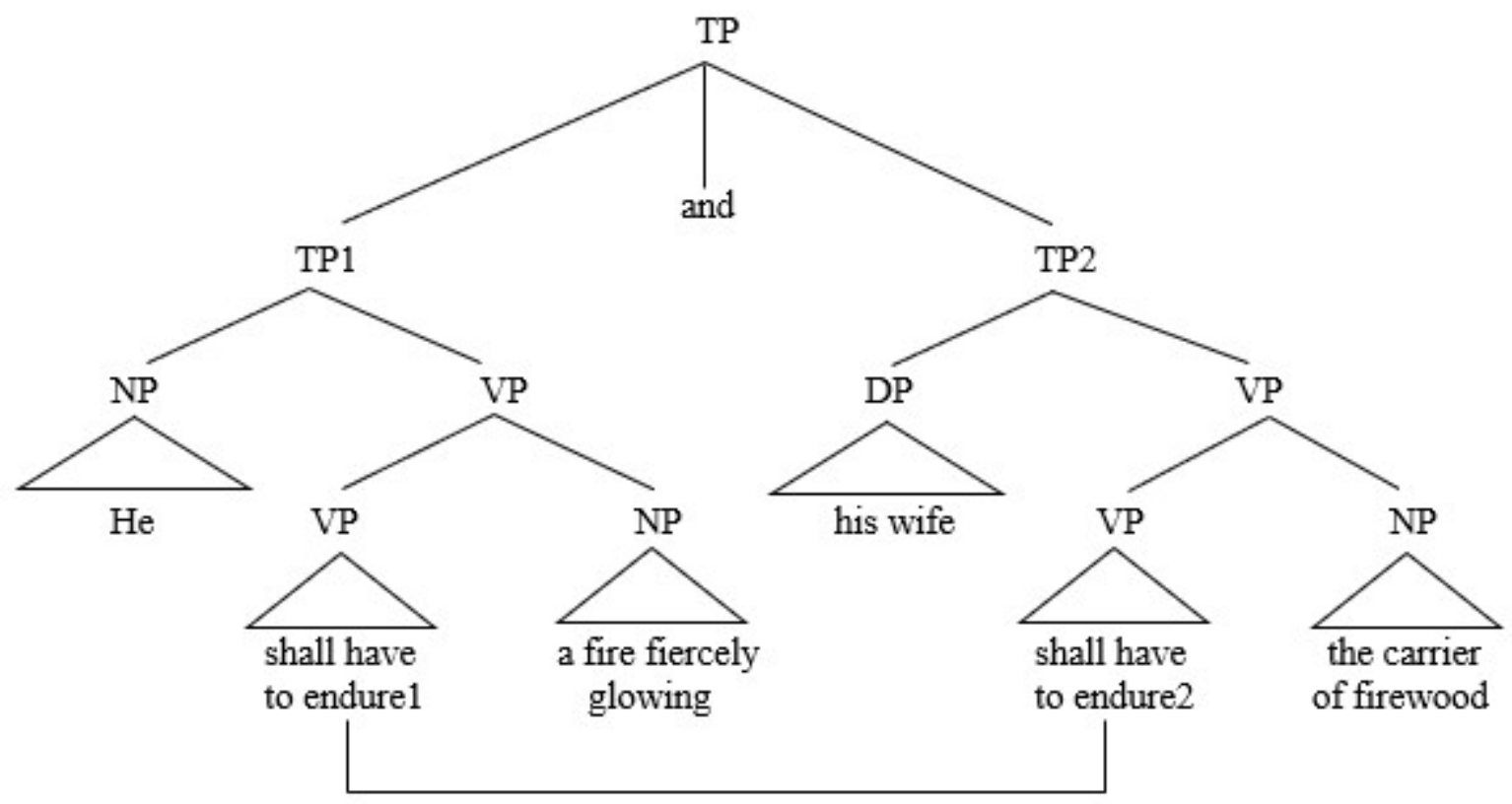

Figure 6. A restoration of the omitted verb in the second conjunct

Arab World English Journal for Translation \& Literary Studies

ISSN: 2550-1542 | www.awej-tls.org 
Due to ellipsis, the Across-the-Board (ATB) movement in verse 4 involves the elliptical remnants his wife and the carrier of firewood that remain after the omitted verb shall have to endure has been omitted from the second conjunct. A re-distribution of both the first and second conjuncts is now possible. The remnants in the second conjunct that appear to the left and the right of the omitted verb shift position as shown in Figure seven:

$\mathrm{He}$ shall have to endure a fire fiercely glowing, and his wife shall have to endure the carrier of firewood.

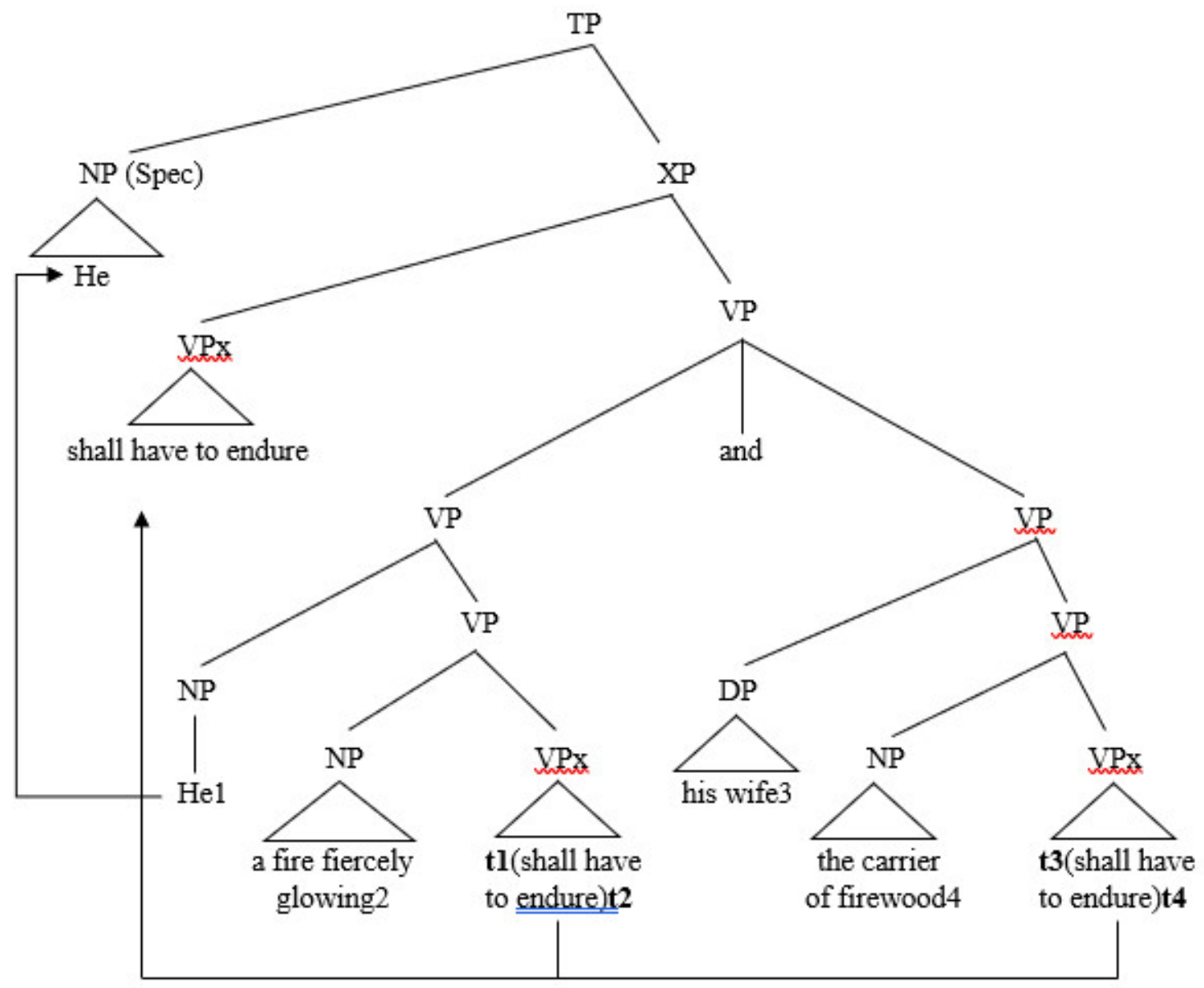

Figure 7. A re-distribution of the first and the second conjuncts

First Conjunct:

1. movement of the subject $\mathrm{He}$ to Spec, TP

2. movement of the object a fire fiercely glowing to a VP-adjoined position

3. ATB-movement of the vacated VP

Second Conjunct:

4. movement of the subject his wife to a VP-adjoined position

5. movement of the object the carrier of firewood to a VP-adjoined position

6. ATB-movement of the vacated VP

The omitted verb shall have to endure is still dormant syntactically in the second conjunct, but it remains semantically functional because the remnants are dependent on it. According to this 
analysis of elliptical gapping and semantic dependency, the phrase carrier of firewood is not a modifier to his wife, but an object of the omitted verb shall have to endure. As such, the carrier of firewood refers to Hell, not to Abu Lahab's wife. If it refers to Abu Lahab's wife, then the meaning of the statement would be incomprehensible:

And his wife shall have to endure the carrier of firewood (herself)

Thus, the English translation of the second conjunct could be based on the following underlying processes of ellipsis and semantic transformation:

1. and his wife shall have to endure the carrier of firewood (+ Literal translation)

2. and his wife shall have to endure Hell (+ Semantic Translation)

3. and his wife shall have tondre Hell (+ Ellipsis)

4. and his wife Hell

Three verses from different chapters in the Qur' an validate this interpretation of firewood to mean fuel of the fire in Hell:

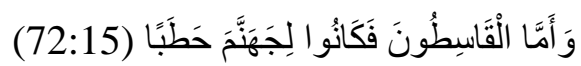

And as for those who are unjust, they are firewood for hell (Pickthall, 2002, p. 598)

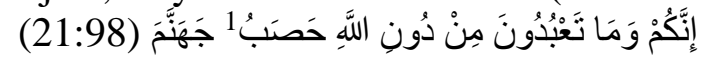

Lo! ye (idolaters) and that which ye worship beside Allah are fuel of hell (Pickthall, 2002, p. 303)

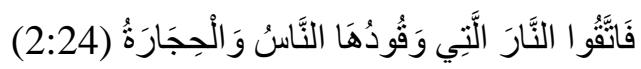

then guard yourselves against the fire prepared for disbelievers, whose fuel is of men [people] and stones (Pickthall, 2002, p. 8)

The three verses clearly show that firewood does not refer to wood, but it refers to the unbelievers and their idols. Therefore, the carrier of firewood in al-Masad cannot refer to the wife of Abu Lahab because this leads to inconsistency in the meaning of the word firewood in the Qur' an as a unified organic and semantic whole. According to this reasoning, the carrier of firewood means Hell itself, and consequently, the translation of verse three and four in al-Masad is as follows:

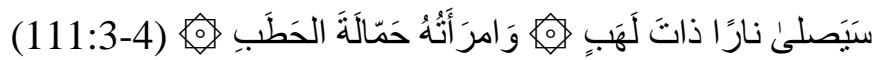

he shall have to endure a fire fiercely glowing; $\$$ and his wife, likewise, shall have to endure fire in Hell

In contrast to the mainstream translation, such as Asad's: he shall have to endure a fire fiercely glowing $\$$ together with his wife, that carrier of evil tales (Asad, 1313)

\footnotetext{
${ }^{1}$ Bellamy (1993) argues that the Arabic word حَصَب haṣab is a corruption of the word حَبَ hatab which means firewood resulting from faulty copying by scribes. He maintains, "It is easy to see how the mistake occurred; in copying hatab, the scribe forgot to write the vertical stroke of the (b/t), turning it into a (ص/s) (p. 564).
} 
A footnote can be added to inform the reader that the word Hell in the verse "and his wife, likewise, shall have to endure fire in Hell" is an interpretation of the carrier of woodfire. Whether the translator should refer to other interpretations of the carrier of firewood found in Tafäsīr is left for the translator to decide.

\section{Ar-Rahmān: Merciful vs. Punisher}

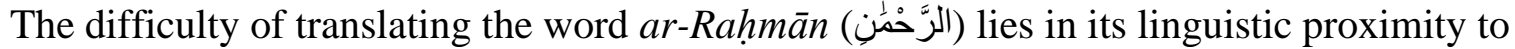
another word which is ar-Rahim (الرَّحِي). Both ar-Rahmān and ar-Rahimm are conjugated in the Basmala, ${ }^{2}$ as well as in chapters $1,2,3,22,30$, and 163 . The two words are derived from the same noun rahmm $(\mathcal{a})$, which means mercy, and both are adjectives that denote the profusion of mercy, called in Arabic emphatic adjectives. Due to this proximity, Sale (2017) translates the two words into the Most Merciful. More recent translators, however, render the two words distinctly as shown in the list:

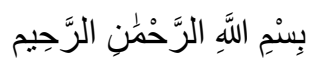

1. In the name of Allah, the Most Beneficent, the Most Merciful (Khān \& Hilālī, 1984)

2. In the name of Allah, the Entirely Merciful, the Especially Merciful (Assami, Kennedy \& Bantley, 1997)

3. In the name of God, the Merciful, the Compassionate (Arberry, 1996)

4. In the name of Allah, the Beneficent, the Merciful (Ali, 1990)

The various translations above indicate several issues. First, there is no agreement among translators as to what the words ar-Rahmān and ar-Rahim precisely mean and how they are differentiated. Ar-Rahmōn is translated as the Most Beneficent, the Entirely Merciful, the Merciful, or the Beneficent. Ar-Rahim, however, is rendered as the (Most) Merciful or the Compassionate. Second, there is confusion among translators in using the word Merciful sometimes to mean arRahmān and sometimes ar-Rahìm and at other times both. Third, there is an attempt to differentiate between the two words lexically or semantically. In Saheeh International, the same word Merciful is used for both ar-Rahmān and ar-Rahìm but with the modifiers Entirely and Especially to differentiate between the two. The semantic differentiation between the words Entirely and Especially is not based on the Qur'anic text itself, but on the explanation found in a secondary interpretative text which the translators chose to ignore mentioning. The source could be Madārij al-Sālikīn (Steps of the Seekers) by al-Jawzīyah (1980, pp.42-43) or al-Maqșad al-Asnā by alGhazāli (p.13-18). Both these exegeses interpret ar-Rahmmān differentiating it from ar-Rahìm based on the meaning of $\operatorname{ar}-R a h m \bar{a} n$ in these verses:

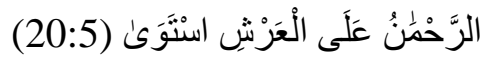

The Most Merciful [who is] above the Throne established (Assami et al., Kennedy \& Bantley, 1997, p. 420)

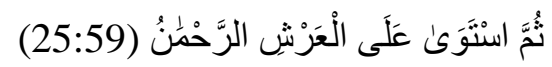

\footnotetext{
${ }^{2}$ The Basmala is the invocation that appears at the beginning of every Qur' anic chapter except the ninth chapter, titled al-Taubah or al-Barā'a.
} 
and then established Himself above the Throne - the Most Merciful (Assami et al., 1997, p. 499)

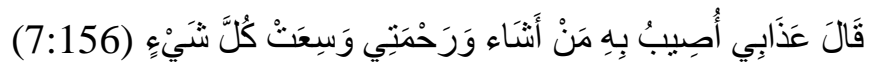

My scourge I will visit upon whom I please: yet My mercy encompasses all things (Dawood, 2003, p. 155)

Ibn Qayyim al-Jawzīyah (1980) deduces from the first two verses that $\operatorname{ar-Rahmann}$ is used to describe God on his throne, and since the throne is all-encompassing of God's creatures, the mercy by ar-Raḥmān must be all-encompassing as well. (p. 37)- According to Al-Ghazāli (1970), arRahmān is the Entirely Merciful in that His:

All-inclusive mercy gives [sic] to both the worthy and unworthy. The mercy of God is perfect and all-inclusive. It is perfect in the sense that He not only wills the satisfaction of the needs of the needy but actually satisfies them. It is all-inclusive in that it includes the worthy the unworthy ... Thus He is in truth the Compassionate absolutely. (pp.13-14)

In another translation (Nasr et al., 2015), the differentiation is made more explicit by the following explanation:

ar-Rahmān is like the light of the sun that illuminates the whole sky, and ar-Rahīm is like the particular ray of sunlight that touches a creature ... Together these two names refer to two aspects of the Divine Mercy (rahma): one essential and universal, the other attributive and particular. (p. 7).

Other translators diametrically reverse the above translation and render ar-Rahmān Especially Merciful and ar-Rahīm Entirely Merciful based on two grammatical viewpoints. The first one views ar-Rahmān as a noun, not an adjective, that is used exclusively for God and cannot be assigned to human beings, whereas ar-Rahim is an adjective which can be used to describe someone as in the sentence: "Ali is rahīm towards his children." Furthermore, the word ar-Rahmān is used as a noun, not an adjective in verse 17, chapter 110, "Call upon Allah, or call upon Rahman: by whatever name ye call upon Him, (it is well): for to Him belong the Most Beautiful Names" (Ali, 1990, p. 813).

The other grammatical viewpoint has it that ar-Rahmān is an adjective that falls within the category of adjectives with the phonetic sound fa lān such as ghadbhān or ațshān. The word ghadbhān means angry, while ațshān means thirsty. Fa lān is an adjectival form which connotes a temporary element about it, i.e., once anger subsides and thirst quenched, the adjectives ghadbhān and ațshān are no more functional. Because Rahmān has the phonetic sound $f a$ ' lān, it implies the temporal sense, not the absolute as ar-Rahim. This grammatical explication justifies the translation of the Basmala thus, In the name of Allah, the Especially Merciful, the Entirely Merciful. However, one wonders if an English native reader would understand the Especially Merciful, the Entirely Merciful as intended by the translator in terms of temporary and absolute mercifulness. Moreover, one might justifiably argue that there is redundancy in the use of the word Merciful. To yield a translation that is clear to the reader, what is needed is an examination of how other verses in the 
Qur' an collocate the word ar-Rahmān, which is related to mercy, strangely enough with inflicting punishment:

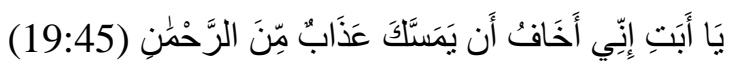

O my father, indeed I fear that there will touch you a punishment from the Most Merciful [ar-Raḥmān] so you would be to Satan a companion (in Hellfire) (Assami, Kennedy and Bantley, 1997, p. 413)

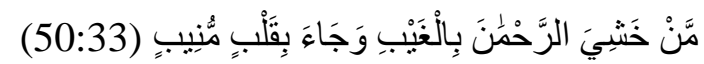

Who fears the Beneficent [ar-Raḥmān] in secret and comes with a contrite heart (Pickthall, p. 513)

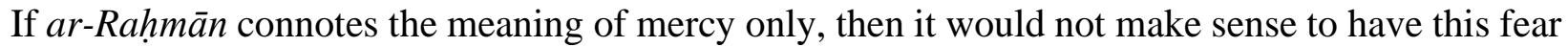
of God as ar-Rahmān, i.e., All Merciful. According to the Islamic notion of sin and punishment, sinners deserve punishment. However, God does not always punish them instantaneously, and it is precisely in this sense that He is $\operatorname{ar}-\mathrm{Rahmm} \bar{a}$. The deferment of punishment does not annul it, and this is the reason why the fear of punishment is concomitant with ar-Rahmān. In chapters 19 and 67, furthermore, ar-Rahmān overtly refers to God when He does not inflict punishment on those who go astray:

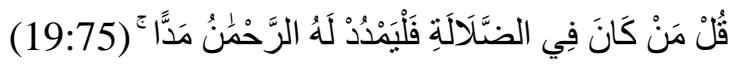

Say: "Whoever is in error, then surely Ar-Rahman would extend to him a respite . . ." (Omar, 2002, p. 297)

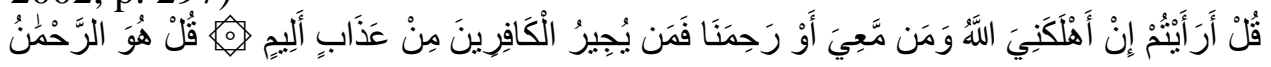

$$
(67: 28-29) \ldots
$$

Say, [O Muhammad], "Have you considered: whether Allah should cause my death and those with me or have mercy upon us, who can protect the disbelievers from a painful punishment?" Say, "He is the Most Merciful [ar-Raḥmān] ..." (Assami et al., 1997, p. 815)

According to this semantic view of $\operatorname{ar-Rahmann}$ as a word that means God when suspending his punishment, the translation should consider ar-Rahmān as a noun that has no equivalent in the English language, whereas ar-Rahìm can be translated as the Merciful. Al-Ġhazālī (1970) states:

ar-Raḥmān is more specific than ar-Rahịm and therefore is applied to God, but ar-Rahịm may be applied to one other than He. In this respect, it approximates the name 'God' which functions as a proper noun, even though it is definitely derived from rahma. (p. 14)

As a proper noun, ar-Rahmān cannot be equated with the adjective (All) Merciful. Therefore, it should be translated using the borrowing method because ar-Rahmān is a noun that has no equivalent in English, just like the word Allah preceding it:

In the name of Allah, ar-Raḥmān, the All Merciful

An additional footnote can be added to clarify that ar-Rahmān means the One who shows mercy by the suspension of punishment deserved by wrong-doers, unlike the word ar-Rahim which is 
used to signify showing mercy regardless of deserving punishment or not, as used in the following verse by Pickthall (2002):

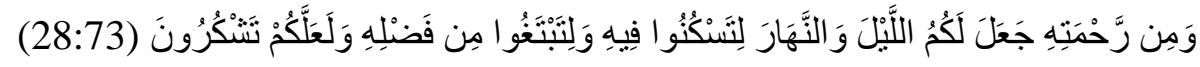

Of His mercy hath He appointed for you night and day, that therein ye may rest, and that ye may seek His bounty, and that haply ye may be thankful (p. 367)

The only consistent translation of (الرَّحْمُنِ) into English as ar-Rahmān, an untranslatable noun, is that of Omar (2002) whose approach is to avoid the cumbersome exegeses for he believes that "the translators followed and adopted an easy approach and tried to interpret the concepts through sources completely external ... a and foreign to the Scripture. They made the people victim to a commentary based on human sources" (p. 7). This denouncement of exegetes and commentators coincides with the view of Reza Aslan (2008) who praises translators who jettison traditional Tafāsìr:

The new crop of Quran translators are [sic] brushing aside centuries of traditionalist, maledominated, and often misogynistic clerical interpretations in favor of a more contemporary, more individualized, and often more gender-friendly approach to the Quran. In the process, they are not only reshaping the way Islam's holy book is read; they are reinterpreting the way Islam itself is being understood in the modern world. (p. 5)

\section{Conclusion}

The finding of the study lead to the conclusion that many translations of the Qur'an disregard possible interpretations because of rehashing interpretations handed down from traditional exegeses. The yardstick to measure whether a translation of the Qur'anic text is acceptable or not has been for a long time based on its compatibility with tradition. As a consequence, the individual talent of the translator as an interpreter has been held in check. The claim that the only acceptable translation is the one which is based on already existing interpretations makes translation a mechanic process denying translators the right to perform their hermeneutic role. When traditional Mufassirs interpreted the Qur'an, they understood it from their horizon. However, translators read it today and understand it from their horizon because reading is a historical event par excellence.

The Qur'anic text is permeated with spots of indeterminacy that have open semantic potentialities, and every interpretation is a concretization of one of these semantic potentialities. However, the enthusiasm for "brushing aside" traditional interpretations is indiscreet because translators would lose the historical sense which, according to T. S. Eliot (1960), is a prerequisite for writers to realize their individual talent (p. 44). Translators, like artists, cannot have their meanings alone.

\section{Notes:}

1. Tafâsīr is the plural form of Tafsīr in Arabic. Tafāsìr are the exegeses or the interpretations of the Qur'an produced by Mufassirs, i.e., Islamic scholars versed in interpretation. Mufassirs must have mastery of 'ilm al-Tafsīr (the Science of Interpretation) and Usūl al-Tafsìr (the Methodology of Interpretation). 
2. A weak Hadith is a saying that is attributed to the Prophet but evaluated under the scrutiny of scholars as inauthentic. It is not accepted in the interpretation of the Qur'an. See (pp.Chap. 3, 114115) in al-Dhahabi, Mohammed Hussein. al-Tafsìr wa al-Mufassirūn. vol. 1. Cairo: Maktabat Wahba, 2000.

3. The original name of the Prophet's uncle is Abd al-Uzza.

\section{About the Author:}

Raed A. Qassas is currently an assistant professor of English Literature at Taibah University (KSA). He has taught several courses on British and American literature, in addition to courses on Postcolonialism, Literary Theory, and Translation. His main research area is literary theory and interpretation, which he formalized in his $\mathrm{PhD}$ (2016). He published a book entitled Resolution and the Briefest End: Suicide in Shakespeare's Tragedies in 2011. His more recent publication in 2020 is an article titled "Reading and Writing: Narrative Motifs of Sexual and Epistemic Violence in Waiting for the Barbarians.” ORCiD ID https://orcid.org/0000-0002-3824-2553

\section{References}

Al-Dhahabi, M. H. (2010). Al-Tafsìr wa al-Mufassirūn [Interpretertation and Interpreters], 1. Cairo: Maktabat Wahba.

Al-Ghazāli, A. M. (1970). Ninety-nine Names of God in Islam: A Translation of the Major Portion of al-Ghazāli's al-Maqșad al-Asnā (R. Stade, Trans.). Ibadan, Nigeria: Daystar Press.

Ali, A. Y. (1990). The Holy Qur'ān: English Translation of the Meanings and Commentary. Madinah, KSA: King Fahd Holy Qur'ān Printing Complex.

Al-Jawzīyah, M. Q. (1980). Madārij al-Sālikīn. [Steps of the Seekers]. Beirut: Dar al-Kutub al'Ilmiyah.

Al-Qurțubi, M. A. (2006). Al-Jami'li Ahkam al-Qur'an (Tafsir Al-Qurțubi). [The Interpretation of Al-Qurțbi]. 20. Beirut: Ar-Risala.

Al-Shawkān̄̄, M. A. (1994). Fatḥ al-Qadīr, al-Jāmi` Bayna Fannay al-Riwāyah wa-al-Dirāyah min 'Ilm al-Tafsir [The Revealation of the Almighty between the Two Arts of Narration and Resoning in the Science of Interpretation], 5. Cairo: Dar al-Wafa.

Al-Tirmidhi, A. M. (1996). AL-Jami 'AL-Kabīr Sunan AL-Tirmidhi [The Major Collection of Hadith by Al-Tirmidhi], vol. 5. Beirut: Dār Al-Ġharb Al-Islami.

Arberry, A. J. (1996). The Koran Interpreted. New York: Touchstone.

Asad, M. (2012). The Message of the Qur'ān. Bristol: Book Foundation.

Aslan, R. (2008). How To Read the Quran: A New Translation Captures the Confusion. Available: https://www.slate.com/culture/2008/11/a-new-translation-of-the-quran.html.

Assami, E., Kennedy, M., \& Bantley, A. (1997). Saheeh International-The Qur'ān: Arabic Text with Corresponding English Meanings. Jeddah, Saudi Arabia: Abul-Qasim Pub. House.

Bellamy, J. A. (1993). Some Proposed Emendations to the Text of the Koran. Journal of the American Oriental Society, 113(4), 562-573. https://doi.org/10.2307/605787.

Boyle, D. (2007). Revealed: How three white American women who converted to Islam wrote the English translation of the Koran which became ISIS fighters' favorite. Available:

Arab World English Journal for Translation \& Literary Studies 
https://www.dailymail.co.uk/news/article-4353740/How-three-American-womentranslated-Koran-English.html.

Bussmann, H. (1996). Routledge Dictionary of Language and Linguistics. London: Routledge. Dawood, N. J. (2003). The Koran. London: Penguin Books.

Doğan, R. (2015). Usūl Al-Fiqh: Methodology of Islamic Jurisprudence. New Jersey: Tughra Books.

Eliot, T. S. (1960). The Sacred Wood: Essays on Poetry and Criticism. London: Methuen.

Gadamer, H.G. (2008). Philosophical Hermeneutics. (D. Linge, Trans.). Berkeley: University of California Press.

Ibn Kathīr, I. U. (2000). Tafsìr al-Qur'ān al- 'Azìm [The Interpretation of the Glorious Qur'ān], vol. 14. Cairo: Mu'assasat Qurtuba.

Ibn Taymiyyah, T. A. (2012). Al-Tafsìr Al-Kabïr [The Comprehensive Interpretation], vol. 7. Beirut: Dar al-Qutub al-Ilmiyah.

Khān, M. M., \& Hilālī, T. A. (1984). Interpretation of the Meanings of the Noble Qur'an in the English Language. Madina, Saudi Arabia: King Fahd Holy Qur'ān Printing Complex.

Levinson, S. C. (2000). Presumptive Meanings: The Theory of Generalized Conversational Implicature. Cambridge, MA: MIT Press.

Nasr, S. H., Dagli, C. K., Dakake, M. M., Lumbard, J. E. B., Rustom, M. (Eds.). (2015). The Study Quran: A New Translation and Commentary. New York, NY: HarperOne, an imprint of Harpercollins.

Omar, K. (2002). Al-Kitab: Prolegomenon, Translation, and Commentary of the Quran. Karachi: Self-published.

Pickthall, M. M. (2002). The Meaning of the Glorious Koran: An Explanatory Translation. Beltsville, MD: Amana.

Qattan, M. K. (2009). Mabāhith Fi 'ulum Al-Qur'ān [Investigations in the Sciences of the Qur'ān]. Beirut: Mu'assasat Al-Risalah.

Rodwell, J. M. (1994). The Koran. London: Phoenix Press.

Saeed, A. (2006). Interpreting the Qur'än: Towards a Contemporary Approach. London: Routledge.

Sale, G. (2017). The Koran: Commonly Called the Alcoran of Mohammed. London: J. Wilcox.

Schleiermacher, F. (2012). On the Different Methods of Translating (S. Bernosky, trans. $3^{\text {rd }}$ ed., pp. 43-63). London: Routledge.

Wheeler, B. M. (2002). Prophets in the Quran: An Introduction to the Quran and Muslim Exegesis. London: Continuum.

Winkler, S. (2005). Ellipsis and Focus in Generative Grammar. Berlin: Mouton De Gruyter. 